\title{
The Buddha as I: Selfhood and Identity in Śrìmālādevī-simhanāda-sūtra
}

\author{
Jarosław Zapart \\ Chair for Comparative Studies of Civilizations \\ Jagiellonian University
}

\begin{abstract}
This article undertakes the issue of the Mahāyāna Buddhist concept of tathägatagarbha, seen as a form of selfhood. Its task lies in outlining the methods employed to disclose tathagatagarbha as a "true" and "original" - but also utterly Buddhist - form of self. In the first part of the article I demonstrate the stance of sütras from the Mahāparinirvāna-mahāsūtra group, in which tathāgatagarbha is bluntly termed ätman, and which posit that all ideas of selfhood are derivatives of the notion of tathāgatagarbha. In the second part, where the Śrimālādevī-sütra is taken under consideration, I introduce an interpretative strategy that shows how this scripture establishes tathagatagarbha as an enduring self. This is done mainly by assigning the tathagatagarbha a function of sustaining the diachronic coherence of sentient beings in samsāra. Consequently, tathāgatagarbha can be viewed as a "prototype" for the idea of "base consciousness" (älayavijñāna). The final part of the article is built around the question of why Śrimañāadevi-sūtra warns against ascribing the label atman to tathagatagarbha.
\end{abstract}

Key words: Buddhism, Mahāyāna, self, buddha nature, ātman, tathāgatagarbha, Mahāparinirvāṇamahāsūtra, Śrīmālādevī-sūtra

Słowa kluczowe: buddyzm, mahajana, jaźń, natura buddy, ātman, tathāgatagarbha, Mahāparinirvāna-mahāsūtra, Śrīmālādevī-sūtra

\section{Introduction*}

According to a widely accepted classification, the most important sütras of the tathāgatagarbha tradition can be assigned to two main groups. The first consists of the Tathāgatagarbhasūtra (TGS), the Anūnatvāpūrnatvanirdeśaparivarta (AAN),

* I would like to express my gratitude to Chris V. Jones from the University of Oxford for sending me his unpublished conference paper (The Term Ätman in Mahāyāna Tathāgatagarbha Thought). Parts 2 $\& 3$ of this article follow his research presented therein. (An expanded version of Jones's paper, entitled The Self-Aggrandizing Vehicle: Tathägatagarbha, Tïrthikas, and the True Self, "Journal of International 
and the Śrimālādevī-simhanāda-sütra (ŚMS). It is assumed that they were created in this very order. ${ }^{1}$ The second group of the tathägatagarbha "canon" is named after the Mahāparinirvāna-mahāsūtra (MPNS), and also contains the Mahāmeghasūtra (MMS), the *Mahābherīhārakasütra (MBhS), and the Añgulimālīyasūtra (AMS). These scriptures share a number of doctrinal similarities and are bound by a prophecy made 700 years after the Buddha's parinirvāna. It concerns a number of tathägatagarbha scriptures that are said to have emerged 40 years after the passing of Śäkyamuni and then disappeared, only to come to light again 80 years before the 700-year mark in the southern part of India, at the time of the Sātavāhana dynasty $(48-181 \mathrm{CE}) .^{2}$

There are several topics discussed frequently, but in varying proportions, in the sütras of the MPNS group. Among them we can include the notion of the eternity of the Buddha, the secret teachings on the parinirvanna, and the prophecy connected with it, a discussion on the icchantikas, the recognising of Mahākāśyapa as the true heir to the Dharma, and the promotion of faith (xin 信) as a means indispensable for achieving liberation. ${ }^{3}$ The Mahāparinirvāna group also shares with many Mahāyāna sūtras a general depreciation of śrāvakas and pratyekabuddhas. However, its most striking doctrinal component must be the identification of tathāgatagarbha or *buddhadhātu with ätman (wo 我) / àtmadhātu (wojie 我界). ${ }^{4}$ The TGS group represents a less unambiguous approach to this matter. This issue will be treated in more detail below.

It must be noted that both groups share a set of ideas that are fundamental, although not exclusive, to the tathaggatagarbha "canon." These are the notion of the decline of Dharma (MPNS group, SMS, AAN), the idea of sattvadhātu (the sphere of living beings equal to dharmakāya, AAN, MBhS, AMS), ekadhātu (reality as a single realm, AAN, AMS), ekayāna (one vehicle leading to enlightenment, MBhS, ŚMS), and the notion of prakrtipariśuddhacitta - an inherently pure mind covered by adventitious defilements (ägantukakleśa) (AAN, ŚMS). ${ }^{5}$

Until recently, all claims regarding the chronology of the texts in question were based on the research of Takasaki (1975), who considered TGS, ŚMS, and AAN to be not only closely related, but also the oldest of all tathägatagarbha sütras. Their relationship seems to be confirmed by Ratnagotravibhāga (RGV), the main śāstra of the tathägatagarbha tradition, which quotes them extensively, and in fact builds many of its doctrinal themes around notions drawn from ŚMS. The views of Takasaki were

\footnotetext{
Association of Buddhist Studies" 2017, vol. 39, pp. 115-170, appeared when the present study was already completed). I am also very grateful to an anonymous reviewer for many highly valuable remarks and emendations.

${ }^{1}$ According to J.A. Silk, the manner of presentation of crucial ideas (sattvadhātu, tathāgatagarbha, dharmakāya) in the AAN validates placing this sütra chronologically after TGS and ŚMS (idem, Buddhist Cosmic Unity, Hamburg 2015, pp. 10-13).

${ }^{2}$ M. Radich, The Mahāparinirvāna-mahāsūtra and the Emergence of Tathāgatagarbha Doctrine, Hamburg 2015, p. 75.

${ }^{3}$ This is also a strong notion in the ŚMS and RGV (see fn. 40).

${ }^{4}$ M. Radich, Tathāgatagarbha Sütras [in:] Brill's Encyclopedia of Buddhism, vol. 1: Literature and Languages, J. Silk et al. (eds.), Leiden 2015, p. 269.

5 Ibidem, pp. 269-270.
} 
held up by M. Zimmermann in his influential study of the TGS (2002), in which he argued that this text might be the first to put forward the idea of tathagatagarbha as "buddha within." However, according to the latest research of S. Hodge (2012) and M. Radich (2015), the status of the oldest tathägatagarbha text should be assigned to MPNS. There is strong evidence that enables us to place the creation of the oldest strata of the MPNS at the beginning of the first millennium under the rule of the late Santavāhana dynasty. This, most definitely, puts MPNS well before any of the texts from the TGS group. ${ }^{6}$

The two bodies of texts are best differentiated by their approach to the notion of tathaggatagarbha and by relating this notion to the idea of a subjective principle usually termed ätman. In TGS, tathägatagarbha should be read as a bahuvrīhi compound denoting living beings having a tathägata, or in fact being nothing other than a buddha. However, in texts which equate tathägatagarbha with *buddhadhātu, this expression is best read as a tatpurușa compound denoting living beings in possession of a buddha-embryo, i.e. a separate entity inside beings. ${ }^{7}$ The recognition of tathāgatagarbha as ätman in the MPNS group not only constitutes a substantial departure from the usual Buddhist anātmavāda approach, but also differentiates this text from the TGS group, in which such equation is absent. In a sütra as rudimentary as TGS, no explicit mentions of tathägatagarbha as a self are made. The same can be said about AAN. Nevertheless, the question of tathaggatagarbha being a kind of attman-like principle is tackled by ŚMS, albeit in a manner different from that introduced by MPNS.

\section{Tathägatagarbha as a true self in the Mahäparinirvāna- mahāsūtra and ${ }^{\star}$ Mahābherīhāraka-sūtra}

In MPNS, the idea of "buddha within" (buddha nature) is expressed with the term *buddhadhātu, which is equivalent to tathāgatagarbha. ${ }^{8}$ This stresses the connection

${ }^{6}$ The date of TGS was set as some time before 350 CE by M. Zimmermann (A Buddha Within: The Tathāgatagarbhasūtra, Tokyo 2002, pp. 77-84). According to A. Wayman, ŚMS was composed around the third century CE (A. Wayman, H. Wayman, The Lion's Roar of Queen Śrimaālā, Delhi 1990, p. 3).

${ }^{7}$ M. Radich, The Mahāparinirvāna-mahāsūtra..., pp. 25-27; C.V. Jones, Beings, Non-Beings, and Buddhas: Contrasting Notions of Tathāgatagarbha in the Anu natvāpūrnatvamrdeśaparivarta and *Mahābherī Sūtra, "Journal of the Oxford Centre for Buddhist Studies" 2016, vol. 10, pp. 53-54.

${ }^{8}$ In MPNS the concept of buddha nature was formed partly under the influence of the MMS. It was a process also connected with the change of the authorship of MPNS. In the first phase, the initial group of authors (dharmakathikas ["dharma preachers"]) defined the notion of àtman as simply the tathägata's dharmakāya, and gave it the characteristics of being eternal, almighty, and unconditioned. According to the theory of Suzuki Takayasu, at that point the tathāgata was not yet treated as an individual self. MMS defined ätman in the same manner, but added the attribute of "non-emptiness" (cf. tathagatagarbha as śünya-aśünya in ŚMS). Inspired by MMS, the second group of MPNS authors (bodhisattvas), having accepted this quality, characterised the tathägata-ätman further as embodied and immanent. Only then was it possible to internalise the tathāgata (or, more precisely, the tathägata's relics) as tathāgatagarbha / * buddhadhātu (see note below), T. Suzuki, The Recompilation of the Mahāparinirvanasütra Under the Influence of the Mahämeghasūtra, "Journal of Indian and Buddhist Studies" 2001, vol. 49, no. 2; see 
of the said concept with the idea of buddha relics ( ${ }^{*}$ buddhadhātu $=$ śarìradhātu). ${ }^{9}$ In MPNS,${ }^{10}$ we find an explicit passage that may be regarded as the purest example of assigning the character and function of self to buddha nature. It is a clear reference to the omnipresent topos of tathagatagarbha present in all beings, but covered with various mental stains, i.e. being available, but not (yet) manifested.

The Buddha addressed Kāśyapa: the true (zhenshi 眞實) self ( $w o$ 我) is the buddha nature (rulai xing 如來性). It should be understood that all living beings have it, but in those beings covered with immeasurable afflictions (fannao 煩惱), it is not visible. ${ }^{11}$

The pedagogical stance of the sütra is revealed when it explains how the * buddhadhätu teachings fit into the scheme of the skill-in-means method. It turns out, that - contrary to what might seem intuitive - it is the "orthodox" teachings of no-self (anātman) that should be regarded as skill-in-means (upāya). It is said that the practice (xiu 修) of cultivating non-self (wuwo 無我) of all the dharmas was taught by the Buddha in order to teach and guide (you 誘) sentient beings (T376_12:0883c02-4). This particular upāya is efficient in leading beings to enlightenment, because when practising non-self, they are able to enter nirvana $(883 \mathrm{c} 04-5)$. It is then explicitly stated that the doctrine of non-self is an upayya, because the concept of anatman is named a skilful (fangbian 方便) and secret ( $m i$ 密) teaching, exposed in order to remove the notion of a "worldly self" (suwo 俗我). Only after revealing this teaching was the Buddha able to expound the nature of the tathāgata (rulai xing 如來性); it is this very nature that is termed a true (zhen 眞) and transcendent (lish $i$ 離世) self (883c05-6).

One may observe here that the "orthodox" view of non-self is helpful insofar as it removes the erroneous notions of a mundane self (i.e. the non-Buddhist attman) and leads to nirvāna. But for the complete understanding of what (or who) actually enjoys enlightenment it is indispensable to know the true nature of all beings. It can also be inferred that on the samsāric plane there exists only a false idea of self that must be countered with the teachings of anatman. However, on the supramundane level there is a pure form of selfhood: a tathägata enjoying the bliss of liberation. This being so, we must underline that in MPNS the term attman is used to denote both notions of false and true selfhood. Here one must avoid the simplistic conclusion that the tendency to use this term constitutes a kind of "Brahmanic bent" of the MPNS.

also idem, The Buddhology in the Mahäbherīsūtra Inherited from the Saddharmapundarīka, "Journal of Indian and Buddhist Studies" 2002, vol. 50, no. 2, p. 1015.

${ }_{9}$ According to the now widely accepted theory of Shimoda Masahiro, the veneration of the buddha relics ([śarīra]dhātu) in a stüpa was reworked by the authors of the MPNS into a reverence for the buddha-principle or nature (buddhdhātu / tathägatagarbha) within all living beings. Some aspects of Shimoda's theory in English are available in S. Sasaki, The Mahāparinirvana Sütra and the Origins of Mahāyāna Buddhism, "Japanese Journal of Religious Studies" 1999, vol. 26, no. 1-2, pp. 192-193; see also J. Takasaki, The Tathägatagarbha Theory Reconsidered, "Japanese Journal of Religious Studies" 2000, vol. 27, no. 1-2, pp. 79-81; M. Radich, The Mahāparinirvāna-mahāsūtra ..., pp. 94-95, 159-168.

${ }^{10}$ Faxian's and Buddhabhadra's translation from c. 416-418 CE (Taishō Shinshū Daizōkyō [T] vol. 12 , no. 376).

${ }^{11}$ MPNS T376_12:883b15-17: 佛告迦葉。眞實我者是如來性。當知一切衆生悉有。但彼衆生 無量煩惱覆蔽不現。 
It is rather the effect of a conscious strategy of redefining the origins and history of the concept and the term atman that enabled authors of MPNS to use it freely. This matter will be discussed below. But first let us turn briefly to another sütra from the MPNS group in order to illustrate a slightly different approach to the idea of tathägatagarbha as ätman.

In MBhS, terms like sattvadhātu, tathāgatagarbha, and ätman are used to indicate the nature of all living beings equal in essence to that of a buddha. The meaning of sattvadhātu in this sütra is restricted to an essential component (dhätu) in beings, and lacks the interpretation as "sphere of beings" so characteristic of AAN. ${ }^{12}$ It is therefore not surprising that one of the focal points of $\mathrm{MBhS}$ is bodhi, understood as the emancipation of a self. MBhS holds that enlightenment constitutes a state of supremacy or sovereignty ( $z i z a i$ 自在) impossible to attain in samsāara, and subsequently posits that being able to experience such supremacy means having a permanent (chang 常) self that undergoes liberation "with a form" (youse 有色) (T270_12:296c06-10). ${ }^{13}$ This liberation with supremacy always pertains to the true form of self, i.e. tathaggatagarbha, which has to be distinguished from a false self bound by samsāra, and therefore devoid of supremacy. MBhS explicitly states that, as long as beings wander in samsāra, the self does not attain sovereignty, and for that reason the teaching of anatman is needed to underline the lack of a permanent self in the cycle of transmigration $(296 \mathrm{~b} 22-24,296 \mathrm{c} 18-20) .{ }^{14}$ We can see that this sütra, just like the MPNS, acknowledges the need to posit a permanent self identical to tathagatagarbha and an illusory self which represents the false idea of what selfhood really is, i.e. the buddha (or buddha-embryo) within. Nonetheless, for both texts the àtman remains a proper term for designating every kind of self.

\section{Mistaken notions of self in Mahäparinirvāna-mahāsūtra and Angulimālìya-sūtra}

Having already established the proper notion of self and the notion of non-self as skilful means, MPNS goes on to elaborate on the misapprehension of the true self by non-Buddhists. Again it is said that Buddha expounded the doctrine of anātman in order to wean people away from the mistaken teachings of the tirthikas (waidao 外道) (non-Buddhist thinkers), who accepted the wrong notions of a mundane self (ätman, sattva, jivva) (T376_12:863a7-9). In a parable, the behaviour of tìrthikas is likened to that of a woodworm accidentally leaving a trail which resembles real letters (862c15-17). Those who posit an erroneous notion of self are like that worm. By accident they stumbled upon something valuable - the buddha nature, a proper self - but mistook it for something else, i.e. the notion of a atman.

${ }^{12}$ C.V. Jones, Beings, Non-Beings..., p. 66. For the idea of sattvadhātu as "realm of beings" and its implications see J.A. Silk, op. cit., pp. 14-51.

13 Translation of Gunabhadra (T vol. 12, no. 270).

${ }^{14}$ C.V. Jones, Beings, Non-Beings..., pp. 69-71. 
The latter part of the sütra states that Buddha's original teachings on self were not understood by his audiences. The deluded listeners (tirthikas) misinterpreted these original teachings and gave rise to notions of sattva, ätman, pudgala, and jiv $a$, or a self that is like a lamp the size of a thumb resident in the heart (887c9-12). Here it is clear that the teachings uttered by the Buddha were distorted over the course of time. The effect of this distortion encompasses various Brahmanic notions of selfhood, including the ideas of self found in the Upanișads. In AMS, *buddhadhātu is often substituted by the term ātmadhātu, svadhātu, or simply dhātu. The scripture lists many mistaken notions of self: empirical ones (sattvadhätu, àtman, jīva, pudgala, manuja, mānava) as well as more subtle ones (self the size of a thumb, the size of a millet grain, the size of a hem or sesame seed, self as a heart of a lamp). ${ }^{15}$

AMS also presents a parable on the possible origin of all these wrong notions. It involves the son of Buddha Gautama, Rāhula, inspecting water for insects. Looking into the water, he sees something, but is not entirely sure if it is insects or tiny particles of some sort. His behaviour is compared to that of a bodhisattva on the tenth bhumi, who is scrutinising his own nature, and, while trying to understand what he sees, generates many different views. This supports the idea that for the unenlightened beings there is no proper notion of a self, i.e. right comprehension of tathaggatagarbha, which is hard to realise (nanru 難入) and attainable only for a fully awakened buddha (T120_2:525b24-28). ${ }^{16}$ In this parable, we see an alternative source for the various conceptions of self. They are apparently the works of bodhisattvas who try to grasp the idea of tathagatagarbha and teach it to others, but do so incorrectly. All the same, just like in the MPNS, the source of these many notions of self lies within the Mahāyāna. In this way, all the mistaken models of salvation surrounding the various notions of self present themselves as distorted versions of buddhadharma.

In the end, investigating the aforementioned sütras leaves us with two conclusions that are valuable for further research. First of all, the concept of self (ätman) is an invention of Buddhist tathaggatagarbha scriptures. Their authors adopted a highly specific heuristic strategy which assumes that, when it comes to the notion of a permanent self, all non-Buddhist (and even some Buddhist) thinkers are wrong, but ultimately derive their deformed conceptions from the only correct teaching of tathägatagarbha. ${ }^{17}$ Secondly, it is impossible for unenlightened beings in samsāra to recognise a self. The experience of selfhood is available only for those who attain enlightenment. For that reason, i.e. to guide worldly beings to nirvāna and make them discard all ideas of a mundane self, Buddha taught the doctrine of anātman as a skill-in-means.

15 Idem, The Term Ätman..., p. 8.

16 Translation of Gunabhadra (T vol. 2, no. 120).

${ }_{17}$ C.V. Jones, The Term Atman..., pp. 9-10. We are dealing here with a kind of revisionism aimed at demonstrating the supremacy of MPNS over competing texts and systems of thought. While the idea of self in living beings is generally upheld, the notion of ätman is discarded when seen as something taught by non-Buddhist thinkers, but accepted after being redefined as tathägatagarbha - an original Buddhist invention. 


\section{The idea of self in Śrīmālādevī-simhanāda-sūtra}

As we shall see, the authors of ŚMS are more cautious in applying the term àtman to tathägatagarbha, and in this sütra we never encounter a simple equation of the idea of self and the buddha nature, nor an explicit claim that tathagatagarbha is a true self. This, however, does not mean that the theory of self is absent from this sütra. Just the opposite - ŚMS, just like sütras form the MPNS group, posits a self, but does it in a more roundabout way. In this process, SMS reveals its distinct character: it upholds the general notion of tathägatagarbha as self, but does so by choosing a different rhetoric and a distinctive pedagogical approach, especially concerning the notion of àtman.

To prove the above points, we shall now employ an interpretative strategy that will allow us to read the ŚMS in a manner consistent with the idea of tathaggatagarbha as a self. This will be done by analysing and coordinating five separate features of the sūtra.

\subsection{Tathagatagarbha is the dharma body of buddha covered in defilements}

Because of the said reluctance of the sütra to equate tathägatagarbha with àtman, we have to base our investigation on the straightforward identification of tathaggatagarbha with the buddha's dharma body (dharmakāya). ${ }^{18}$

O Lord, it is so that the dharma body of the tathāgata when it is not free from afflictions is called the tathagatagarbha. ${ }^{19}$

The sütra does not rest with this statement. Elsewhere the dharmakayya is given four "perfect qualities" or "perfections of qualities" (gunapāramitā). They are the perfection of purity (śubhapāramitā), pleasure (sukhapāramitā), permanence (nityapāramitā), and self (wo boluomi 我波羅蜜, ätmapāramitā) (T353_12:222a23-24). ${ }^{20}$ At the same time, tathāgatagarbha is described as garbha of the dharmakāya (fashen zang 法身藏)

${ }^{18}$ The English renderings of ŚMS are modified versions of D. Paul's translations (The Sütra of Queen Śrimālā of the Lion's Roar [in:] D. Paul, J.R. McRae, The Sütra of Queen Śrimālà of the Lion's \& The Vinalakirti Sütra, Berkeley 2004).

${ }^{19}$ Gunabhadra's translation from 435 CE (T vol. 12, no. 353), 221c10-11: 世尊。如是如來法身 不離煩惱藏名如來藏。D. Paul, The Sūtra of Queen Śrimālā..., p. 44. This passage is quoted in RGVV 12.14: bhagavaṃs tathāgatadharmakāyo 'vinirmuktakleśakośas tathāgatagarbhah sūcyate. Cf. A. Wayman, H. Wayman, op. cit., p. 98. For Bodhiruci's translation (703-716 CE), being a part of Ratnakütasūtra, see G.C.C. Chang (ed.), A Treasury of Mahāyāna Sütras, University Park \& London 1983, p. 378.

${ }^{20}$ In earlier Buddhist tradition, these four qualities were "distortions" (viparyāsa) associated with wrong views. For deluded beings it is a mistake to look for purity, pleasure, permanence, and self in samsāra. The correct view lies in cultivating the exact opposite notions (viparyāsaviparyaya), i.e. the lack of purity, pleasure etc. However, for tathägatagarbha literature the viparyāsas are the correct attributes of dharmakāya, and as such indicate right views. See RGV I, 35-36 and the subsequent commentary (RGVV 30.9-18). The MPNS also uses the four viparyāsas, but ascribes them directly to the tathāgatagarbha, which is not surprising (C.V. Jones, Beings, Non-Beings..., p. 56). 
and the inherently pure garbha (zixing qingjing zang 自性清淨藏) (222b22-23). Here the two most popular readings of garbha are applicable. If it is read as "womb," then the whole compound denotes a living being having a (developed) buddha, and if it is read as "embryo," it denotes a being with the buddha body in potentia. Nevertheless, we know for sure that tathagatagarbha is veiled in defilements of an extrinsic nature (222b23-24), so its enlightened features - including the characteristic of selfhood - are not (yet) manifested. Thus the tathägatagarbha, as it constitutes the samsāric "mode" of the enlightened buddha body, cannot represent a permanent and true self par excellence. For that very reason, it is not termed atman, and, by the same token, only that which possesses the quality of self (and functions as such) is characterised as having the "perfection of self." Here, just as with the canonical set of six or ten perfections, pāramitā must indicate an utterly refined quality. And just as prajñāpāramitā means a perfect wisdom resulting in enlightenment, so $\bar{a}$ tmapāramitā must mean excellence or - to recall the MBhS - supremacy of a permanent (nitya) selfhood that enables the enjoyment of deliverance. In this way, by applying the gunapāramitās to dharmakāya and avoiding classifying tathägatagarbha as ätman, SMS on the one hand conforms to the "law" that no self-principle can be recognised in the domain of samsāra, but on the other distinguishes itself from the sütras of the MPNS group.

Because the first argument presented above is central to the whole fivefold interpretative scheme, it is now necessary to summarise the whole chain of reasoning contained in it. As indicated, ŚMS equates the dharmakayya, not free from afflictions, with tathägatagarbha, and also calls the tathāgatagarbha a garbha of the dharmakāya. The sütra predicates àtmapāramitā only of the (transcendent) dharmakāya, but considering the essential equality between the two, we are warranted in inferring that the text would countenance the predication of àtmapāramita of (phenomenal) tathāgatagarbha as well, providing that this "perfection" would be understood as not apparent. That being said, it has to be noted that the sütra's treatment of the idea of self cannot be apprehended without referring to its description of the paradoxical pure-but-impure nature of tathägatagarbha (222b23-24). This in turn must be understood in the light of a distinction between the ontological and epistemological levels. Thus it is essential to clarify that on the ontological level, ŚMS presupposes the existence of one real principle ("buddha nature"). ${ }^{21}$ Only when we turn to the domain of epistemology may the differentiation of this principle into its transcendent/nirvānic (pure) and phenomenal/samsāric (impure) aspect take place. Thus the tathāgatagarbha-cum-dharmakāya is pure and equipped with ätmapāramitā only when perceived by enlightened beings, but when the unenlightened beings - without resorting to faith ${ }^{22}$ - try to grasp it, they see nothing at all, or mistake their buddha nature for a mundane self - impure and deprived of àtmapāramitā . It must be added that all remarks hinting at this seeming duality of the real principle appearing in the pages below should be read according to this logic.

\footnotetext{
${ }^{21}$ See paragraph 4.2 below.

${ }^{22}$ See paragraph 4.5 and fn. 39.
} 


\subsection{Tathägatagarbha is the basis for phenomenal reality}

The next step in promoting the idea of self in ŚMS lies in assigning a crucial metaphysical function to the dharmakāya-tathāgatagarbha - that of a substratum underpinning phenomenal reality.

Tathägatagarbha is separated ( $l i$ 離) from the characteristic (xiang 相) of the conditioned (youwei 有爲). It is eternal (chang zhu 常住), unchanging (bubian 不變), and for that reason it is the basis ( $y i$ 依), the support (chi 持), and the foundation (jianli 建立). O Lord, the tathāgatagarbha is not separate, not severed, and not liberated from the inconceivable dharmas of the buddha. O Lord, it is a basis, support, and foundation for the conditioned dharmas that are severed, separate, and different from the dharmas of the buddha. ${ }^{23}$

Here the sutra uses the term tathagatagarbha, but it is clear that - since it is considered unconditioned (asamskrta) and has the many qualities of a buddha - it must still denote the tathaggatagarbha-cum-enlightened dharma body. In this passage, tathägatagarbha is established as support for all phenomenal reality: every aspect of the conditioned (samskrta) sphere, including living beings, is based on it. The above passage needs to be read together with a different statement according to which all conditioned phenomena are impermanent ( $w u$ chang 無常) and of a false ( $x u$ 虚) and deceptive (wang 妄) nature, and therefore are not to be considered real (fei di 非諦) (221c25-28). Thus, because only dharmakāya, being the "sphere of nirvāna" (niepan jie 涅槃界), is truly unconditioned, we must conclude that, according to ŚMS, the dharmakāya constitutes the only permanent and true reality. This view seems to have its roots in the thought of the Lokottaravāda branch of the Mahāsāṃghika school. Lokottaravādins were the only school that posited unconditioned or transcendent (lokottara) dharmas as the sole truly existing reality. This is important inasmuch as Mahāsāmghikas from the Āndhra region are the most likely candidates for the authorship of ŚMS and other tathāgatagarbha sūtras. ${ }^{24}$

\subsection{Tathägatagarbha is the basis for samsāra. Diachronic factor (I)}

Next, the sütra expounds that tathägatagarbha-dharmakāya serves as a kind of platform for the cycle of birth and death of living beings.

O World Honored One, the cycle of birth and death (shengsi 生死) rests (yi 依) upon the tathāgatagarbha, because the tathāgatagarbha is the original reality [enlightenment] (benji

${ }^{23}$ S MS T353 12:222b10-14: 非如來藏有生有死。如來藏者離有爲相。如來藏常住不變。是 故如來藏。是依是持是建立。世尊。不離不斷不脱不異不思議佛法。世尊。斷脱異外有爲法 依持建立者。是如來藏。For this and two other passages translated below see D. Paul, The Sütra of Queen Śrimālā..., p. 53; cf. A. Wayman, H. Wayman, op. cit., pp. 104-105; G.C.C. Chang, op. cit., p. 38.

${ }^{24}$ A. Wayman, H. Wayman, op. cit., pp. 1-3; A. Wayman, The Mahāsāmghika and the Tathägatagarbha, "Journal of the International Association of Buddhist Studies" 1978, vol. 1, no. 1, pp. 42-43; S. Hodge, On the Eschatology of the Mahaparinirvana-Sütra and Related Matters, Lecture held at University of London, SOAS, 2006, http://www.nirvanasutra.net/historicalbackground2.htm [accessed: 16 January 2017]; A.W. Barber, Two Mahāyāna Developments along the Krishna River [in:] Buddhism in the Krishna River Valley of Andhra, S. Padma, A.W. Barber (eds.), New York 2008, pp. 151-167. 
本際), which is unknowable. [...] O Lord, samsāra is the extinction (mo 沒) of senses and in the next phase the arising ( $q i$ 起) of unexperienced senses. This is called the cycle of birth and death. O Lord, the two dharmas of birth (sheng 生) and death ( $s i$ 死) are the tathägatagarbha. It is only a convention to say that there is death and birth. Death is the extinction of senses, birth is the arising of new ones. But the tathägatagarbha is not born and does not die. ${ }^{25}$

While the samsāra consist of a constant repetition of arising and extinction of dharmas, the tathagatagarbha is something that simultaneously participates in phenomenal reality ("Birth and death are the tathägatagarbha") and transcends it ("The tathägatagarbha is not born and does not die"). In other words, it serves as an alternative designation for the whole reality, perceived here in two aspects, i.e. the cycle of birth and death and nirvanna. Naturally, the view expressed in the above passage is one of the existence of a sole permanent principle: the buddha. From the standpoint of the ultimate (paramārtha) - and when we bear in mind the duality of conditioned (unreal) and unconditioned (real) - the participation of tathägatagarbha in the transmigratory cycle is just as illusory as that cycle itself, and appears as something performed only for the sake of beings entrapped in it. However, for those beings who believe in it, tathaggatagarbha is the buddha-element within that serves as a platform for the process of renewing of sense organs in repeated existences. This allows us to call tathāgatagarbha a diachronic principle sustaining the identity of living beings in the transmigratory cycle.

\subsection{Tathägatagarbha is that which strives for nirvāna. Diachronic factor (II)}

In order to keep a balanced account of the tathaggatagarbha as a self, the sütra also accentuates its psychological side.

If there were no tathāgatagarbha, there would be no detest (yan 厭) for pain and pleasure (kule 苦樂), nor a wish (qiu 求) for nirvāna. ${ }^{26}$

Here we find justification for positing tathägatagarbha as an element upon which world weariness and desire for salvation is imprinted. Its existence is necessary because the mental components of a living being are of momentary nature and it is impossible for them to be sufficiently affected with suffering. These mental elements are listed as seven dharmas (qi fa 七法): six sense consciousnesses (liushi 六 識) and the accompanying knowledge of the mental phenomena (xinfa zhi 心法智) (222b16-17). It turns out that tathaggatagarbha fulfils the function of self not only

${ }^{25}$ ŚMS T353 12:222b05-10: 世尊。生死者依如來藏。以如來藏故。説本際不可知。世尊。 [...] 世尊。生死。生死者。諸受根沒。次第不受根起。是名生死。世尊。死生者此二法是如來藏。 世間言説故。有死有生。死者謂根壞。生者新諸根起。非如來藏有生有死。

${ }^{26}$ ŚMS T535_12:222b14-15: 若無如來藏者。不得厭苦樂求涅槃。Quoted in RGVV 36.1-2, but the śástra is more elaborate. It says that without the tathāgatagarbha there would be no desire (icchā) and no wish (prārthanā) for nirvāna, nor a vow (pranidhi) for it. It also clarifies that "desire" denotes here the "lack of cowardliness" (asamkoca) in attaining the intended object, "wish" means "searching for" (parimārgana), and "vow" stands for "will” (cetanā) of the mind (36.5-7). 
in the way discussed above, but also as a principle consciously striving for a way to end suffering.

From the previous analysis (4.1-4.4), we can conclude the following. On the ontological level, tathägatagarbha constitutes all reality in two aspects. This entails its diachronic function as a factor not only supporting the cycle of rebirth, but also making it possible to keep the identity of beings in the cycle of samsāra. On the psychological level, tathaggatagarbha is responsible for seeking enlightenment and carrying the incentive of further practice into the next life. In other words, it is the buddha in potentia that strives to attain the developed form of dharmakāya.

As a permanent factor, tathaggatagarbha seems to operate beyond the five skandhas, and as such has no counterpart in the thought of early Buddhism. However, on the samsāric level it could be interpreted as assuming the diachronic function of mind (citta) or consciousness (vijñäna). Such a function of consciousness was known already in the early Buddhist nikayyas. In the context of the law of dependent origination (pratītyasamutpāda), it is sometimes stated that "name and form" (nämarūpa) and viññana condition each other, and as such constitute a basis for the subsequent existence (SN II, 104). ${ }^{27}$ Elsewhere it is said that viññana is a factor connecting the previous life to a present one, because by entering the mother's womb it causes nämarüpa to be reborn (DN II, 63). ${ }^{28}$ In the same vein, SN II, 65 explicitly states that renewed existence in the future is caused by an established consciousness. ${ }^{29} \mathrm{~A}$ similar diachronic function is given to citta. In SN V, 369-370 a certain Mahānāma is reassured by the Buddha that his mind, refined by practice, will "go to distinction" after his death. ${ }^{30}$ These two factors, however, have a feature that differentiates them from tathāgatagarbha. Even if they are responsible for future rebirths, viññanna and citta are dependent on nammarūpa, and are thus devoid of permanence. Being subjected to constant change, they are not to be identified with a stable transmigrating principle, such as $\bar{a}$ tman. ${ }^{31}$ As we have seen, the tathagatagarbha - unconditioned, equipped with perfections of permanence and self - escapes such limitations.

In AAN, a different sütra from the TGS group, the diachronic function of tathāgatagarbha is presented in a much simpler and direct way. AAN directly equates tathagatagarbha with the enlightened body of the buddha, ${ }^{32}$ and declares that when the dharmakaya in a state of defilement comes and goes through life and death (往來生死, gaticyutyupapattișu samcaran) from beginningless (anavarāgra) times, it is termed (living) beings (sattvadhätu) (T668_16:467b06-08). ${ }^{33}$ The further part of this passage, which concerns tathaggatagarbha in beings, bodhisattvas, and buddhas, is cited in full by RGVV 40.16-41.5, but not commented upon. It seems that RGV

${ }^{27}$ B. Bodhi, The Connected Discourses of the Buddha, Boston 2000, p. 602.

${ }_{28}$ M. Walshe, The Long Discourses of the Buddha, Boston 1995, pp. 225-226.

${ }^{29}$ B. Bodhi, op. cit., p. 576.

${ }^{30}$ Ibidem, p. 1808.

${ }^{31}$ Tse-fu Kuan, Mindfulness in Early Buddhism, London \& New York 2008, pp. 123-124.

${ }^{32}$ In Bodhiruci's translation ( $\mathrm{T}$ vol. 16, no. 668), AAN 467a18-19: 如來藏者即是法身。 "Tathāgatagarbha is precisely the dharma body" (quoted in RGVV 2.11-13); see J.A. Silk, op. cit., p. 94.

${ }^{33}$ Quoted in RGVV 40.16-18, see ibidem, pp. 103-104. 
in general is not especially concerned with the issue at hand. However, it does cite another passage with a similar overtone. It comes from a certain Sadāyatanasūtra, now lost. This text mentions a germ (gotra $)^{34}$ which from beginningless times (anādikālika) moves through samsāara, assuming different forms of living beings with six sense organs (55.16-17).

Since the tathāgatagarbha in ŚMS works as a self responsible for the continuity of existence, it clearly shares some features with the Yogācāra concept of "storehouse consciousness" (älayavijñāna). Tathāgatagarbha's function as the foundation for conditioned dharmas resembles âlayavijūāna as a "storehouse" of sensory input and karmic dispositions that serve as a source for the projection of phenomenal reality. This fact is well illustrated in a much later sütra, the Lan்kāvatāra, a scripture that famously conflates the two ideas in question. The said process is reflected in the Chinese translation of this text, which uses zang 藏 for both tathāgatagarbha (rulaizang 如來藏) and ālayavijñāna (shizang 識藏). ${ }^{35}$ However, taking only the early Yogācāra and Tathāgatagarbha scriptures (Yogācārabhūmi, Saṃdhinirmocana, RGV) into consideration, these two concepts can be differentiated in clear terms. ${ }^{36}$ Tathägatagarbha is unconditioned, inherently pure, and serves as a basis for all phenomenal reality. Alaya, while serving as a similar kind of foundation, is nevertheless dependent on the remaining seven consciousnesses and inherently stained. Its purification, known as the "transformation of the basis" (áśrayaparāvrtti), means a radical change of ālaya's character, while in the context of tathāgatagarbha āśrayaparivrtti it indicates only a refinement of the very same permanent principle (RGVV 21.9-10). ${ }^{37}$ Moreover, whereas in the early buddha nature literature the diachronic function of tathāgatagarbha adds to its overall characteristic as a self, in the context of Yogācāra interpreting àlayavijñana as self is considered a serious error of the distorted mind (kliștamanas). This feature is a good touchstone for differentiating both systems of thought in the era before the fourth or fifth centuries CE, when they were first synthesised in the Lainkāvatārasūtra.

\subsection{Tathägatagarbha is not a mundane self}

We must now turn to the last step in the proposed fivefold strategy, which allows us to interpret tathāgatagarbha as self in ŚMS. Having characterised it as a permanent world-weary and enlightenment-seeking principle, the sütra warns against recognising tathāgatagarbha as a notion equal to various conceptions of selfhood, such as ätman (wo 我), living being (zhongsheng 衆生), soul (ming 命), and person (ren 人)

${ }^{34}$ In RGV the term gotra is often used to mean "cause" (hetu), e.g. in I, 150 where it is said to be the element from which the three bodies of the buddha are obtained. In this aspect, gotra clearly corresponds with (tathāgata)garbha as hetu of future buddhahood, e.g. in I, 27-28.

35 D. Paul, The Concept of Tathāgatagarbha in the Śrīmālādevī Sūtra (Sheng-man Ching), "Journal of the American Oriental Society" 1979, vol. 99, no. 2, p. 192.

${ }^{36}$ For an account of the early sources on ālayavijñāna see W.S. Waldron, The Buddhist Unconscious, London 2003, pp. 91-127.

37 Cf. J. Takasaki, A Study on the Ratnagotravibhāga (Uttaratantra), Rome 1966, p. 187, fn. 6. 
(T353_12:222b19-20). It could be argued that the sole fact of correlating the wrong notions of selfhood, especially âtman, with the tathägatagarbha may imply that there must be a fundamental similarity (of function) between them. Thus a warning against the possibility of confusing them. Of course, it has to be asked why ŚMS negates tathägatagarbha the quality of àtman, while assigning the perfection of self to the enlightened buddha body.

As we have seen, MPNS and MBhS state that there is a "Buddhist self," and are in agreement that this self is transcendent, which means that it is of purely nirvannic character and is to be recognised only by enlightened beings. Therefore, according to MPNS, the Buddha taught the principle of anātman as an upāya in order to wean people away from the notion of a false worldly self, and only when they were able to accept the higher teachings did he expound the doctrine of tathagatagarbha as the true ätman. We have observed that MPNS accepts both the notion of a (true) self and the term ätman to denote it. But this particular strategy is effective only because in this sütra the term atman was redefined to indicate the correct notion of selfhood, i.e. tathāgatagarbha. According to MPNS, the idea of ätman was designed to mean "buddha nature," but over the course of time it was distorted by the tirthikas, so returning to the use of this term as an indicator of the true notion of self must have felt a fully justified step. However, in the ŚMS - a sūtra stemming from a different strand of Indian tathägatagarbha thought - atman remains an iconic example of a mistaken notion of selfhood, i.e. a mundane self. It is an utterly erroneous concept giving a false sense of identity and generating attachment. For this reason, tathägatagarbha is denied the status of atman, and even the enlightened body of the buddha is not termed as such, but is given the perfection of self. It seems that this move was dictated just as much by the necessity to underline the transcendence of the true self (dharmakāya) as by the need to avoid the use of the term atman for any entity. It is therefore justified to conclude that, on a philosophical level, ŚMS conforms to the MPNS notion of the "buddha within" as the true self of living beings, but chooses a distinct pedagogical approach resulting in different use of categories.

This attitude is very much in tune with the sutra's overall inclination towards presenting its essentially non-dualistic teaching through antithetical categories. This strategy primarily uses the opposition between impure and pure. The impure is always bonded with the samsāric, whereas the pure is always nirvānic. And so ŚMS contrasts the conditioned, impermanent and false with the unconditioned, permanent and true, ${ }^{38}$ the latent state of ignorance (wuming zhudi 無明住地, avidyāvāsabhümi) with the buddha's wisdom (220a12-15), the ultimate refuge (Buddha) with the limited refuges (Dharma and Sangha) (221a02-18), ${ }^{39}$ and the lack of self with the perfection of self. A special case is made of the pair tathägatagarbha / dharmakāya: both are inherently pure, and differentiated only by the unreal adventitious defilements ${ }^{40}$

${ }^{38}$ In the context of the only unconditioned and thus permanent $\&$ true Noble Truth of the extinction of suffering: ŚMS T353_12:221c25-28, 222a01-03.

${ }^{39}$ See also RGV I, $20-21$ and commentary.

40 The inability of unenlightened beings to understand this paradox is a strong notion running through ŚMS and RGV. See ŚMS T353_12:222c03-07 (also RGV I, 25 and subsequent commentary [RGVV 
which assign them to the pure or impure realm. Thus the dharmakāya working (as tathägatagarbha) within samsāra is not-self, but its full form of a permanent self can be revealed through the destruction of taints.

The last step in our fivefold interpretative strategy is closely related to the first. ŚMS warns against equating tathägatagarbha with different notions of self (including ätman), but the reason for this is, of course, not the sütra's denial of a true self, but its insistence on the fact that although the true self is always present, it is unrecognisable on the level of mundane existence by unenlightened beings. Enlightenment, however, which is not a destruction of dharmas, but the gaining of dharmakāya $(221 \mathrm{c} 07-11),{ }^{41}$ seems to be a realised state of selfhood (ātmapāramitā) that enjoys the many buddha qualities. This very state is also the realisation of the wisdom of emptiness (śünyatā) in a model proposed by the sütra itself, where tathāgatagarbha is interpreted as being free from defilements (śünya), but full of enlightened attributes (aśūnya) (221c12-23).

\section{Conclusions}

While the Indian tathāgatagarbha sütras belonging to the MPNS group are the main exponents of the idea of buddha nature as a true self, ŚMS, coming from a different offshoot of tathägatagarbha texts, can also be interpreted as successfully supporting this claim. Working with slightly different categories and applying distinct hermeneutics to the Buddhist tradition, SMS combines the theory of a "Buddhist self" with a more sensitive approach to the conventional anätmavāda position.

To "extract" the discourse on self from the sütra it was necessary to introduce a five-step interpretative strategy. First of all (4.1), we have established that ŚMS proposes a fundamental equality between the enlightened body of the buddha, having the perfection of self with the notion of "buddha within" (tathaggatagarbha), being a "mode" of the buddha body in samsāra. This, however, does not mean that tathägatagarbha constitutes a mundane self in the phenomenal realm, because its equivalence with the dharmakayya on an ontological level is somewhat "nullified" by the cognitive (epistemic) discrepancies between buddhas and unenlightened beings. For this reason, the tathagatagarbha cannot be recognised as wielding the quality of ātmapāramitā by beings still trapped in samsāra. For them, the only way to get in contact with the true self is through faith in buddha's words.

The second and third step entailed constituting tathāgatagarbha as a basis for the conditioned phenomenal reality (4.2) and cycle of rebirth (4.3). This choice was something the authors of the ŚMS inherited from their Mahāsāṃghika background. Every aspect of phenomenal, samsāric reality rests upon the unconditioned and nirvannic. If what is asamskrta is permanent and real, and if the realm of nirvanna is only a different designation for the dharma body of the buddha, this means that the

21.17-22.4]) where it is said that only tathāgatas and highly developed bodhisattvas can understand this issue. The rest must resort to faith ( $x i n$ 信).

${ }^{41}$ See also RGVV 12.10-14 starting with na khalu bhagavan dharmavināśs duhkhanirodhah. 
tathāgatagarbha-cum-dharmakāya constitutes the only permanent reality. This unconditioned principle sustains the conditioned sphere of all phenomena and provides continuation for the illusory human experience as long as it is necessary for the "buddha within" to gain full selfhood.

The fourth step (4.4) of our method established the said principle as that which detests samsāra and strives for nirvāna. By combining this idea with previous arguments it was possible to disclose tathägatagarbha as a stable principle asserting the diachronic continuity of a living being and its original identity of a changeless buddha.

The fifth step (4.5) confirmed that in the ŚMS there can be no equivalence between tathaggatagarbha as a true self and the idea of a mundane self (ätman). What's more, as indicated earlier (4.1), in ŚMS the label "ätman" may be used only as a part of the compound $\bar{a}$ tmapāramitā, denoting the fully enlightened buddha body. Thus, while ŚMS recognises the absence of a worldly self just as the sūtras from MPNS group, it also denies tathägatagarbha the right to wield the label "ätman." This reveals that the sütra regards both the notion of a mundane self and the term indicating it as invalid. Such an attitude, clearly more conservative than the one presented by MPNS, might have been a natural development in the alternative, independent strain of Indian tathaggatagarbha thought represented by ŚMS, but it is also possible that the authors of the sütra knew of the tathaggatagarbha doctrine in $\mathrm{MPNS}^{42}$ and consciously decided not to draw on solutions that seemed too unorthodox.

Finally, something remains to be said about the narrative strategy of ŚMS, which, simultaneously, influences and reflects its pedagogical stance. The sütra's viewpoint is that of ultimate reality, i.e. dharmakāya; this entails a strong notion of "automatism," in which living beings are objectified as "areas of work" for the buddha-principle rather than treated as autonomous subjects. ${ }^{43} \mathrm{~A}$ great effort on their part, except for having faith, is not needed for the plan of salvation to work. This is in conformity with the sütra's teachings on "one vehicle" (ekayāna), according to which all beings possessing tathāgatagarbha will surely reach nirvāna (220c19-26). For this reason, the text may give an impression that ultimately it is the "buddha within" that provides an incentive to undertake practice, strives for enlightenment, while sustaining the identity of beings in consecutive rebirths, reaches maturity by acquiring the dharma body, and overcomes the illusion of phenomenal reality. Such perspective might suggest that beings are deprived of personal karmic responsibilities, but - in the light of the above discussion - it would be better seen as a by-product of the buddha-oriented perspective influencing the sütra's dominant soteriological and pedagogical import that promotes the certainty of enlightenment for all and the ultimate equality of Buddha and the "I."

${ }^{42}$ See C.V. Jones, Beings, Non-Beings..., p. 57.

${ }_{43}$ Cf. M. Zimmermann, The Process of Awakening in Early Texts on Buddha-Nature in India [in:] A Distant Mirror, L. Chen-kuo, M. Radich (eds.), Hamburg 2014, pp. 525-527. 


\section{Bibliography}

A Treasury of Mahāyāna Sūtras. Selections from the Mahāratnakūta Sütra, G.C.C. Chang (ed.), University Park \& London 1983.

Barber A.W., Two Mahāyāna Developments along the Krishna River [in:] Buddhism in the Krishna River Valley of Andhra, S. Padma, A.W. Barber (eds.), New York 2008, pp. 151-167.

Bodhi B., The Connected Discourses of the Buddha. A New Translation of the Samyutta Nikāya, vol. 1-2, Boston 2000.

Hodge S., On the Eschatology of the Mahäparinirvana-Sütra and Related Matters, Lecture held at University of London, SOAS, 2006, http://www.nirvanasutra.net/historicalbackground2.htm [accessed: 16 January 2017].

Hodge S., The Mahāyāna Mahāparinirvana-Sütra. The Text and Its Transmission, Corrected and revised paper presented at the Second International Workshop on the Mahäparinirvana-sütra, University of Munich, 2012, http://www.buddhismuskunde.uni-hamburg.de/fileadmin/pdf/ publikationen/The_Textual_Transmission_of_the_MPNS.pdf [accessed: 16 January 2017].

Jones C.V., Beings, Non-Beings, and Buddhas: Contrasting Notions of Tathägatagarbha in the Ānu natvāpürnatvanirdeśaparivarta and *Mahābherī Sütra, "Journal of the Oxford Centre for Buddhist Studies" 2016, vol. 10, pp. 53-84.

Jones C.V., The Term Ātman in Mahāyāna Tathāgatagarbha Thought, unpublished paper presented at the $17^{\text {th }}$ Congress of the International Association of Buddhist Studies, University of Vienna, Vienna 2014.

Kuan Tse-fu, Mindfulness in Early Buddhism, London \& New York 2008.

Matsuda K., Śrīmālādevīsiṃhanādanirdeśa [in:] Manuscripts in the Schøyen Collection, vol. 1: Buddhist Manuscripts, J. Braarvig et al. (eds.), Oslo 2000, pp. 65-76.

Paul D., The Concept of Tathāgatagarbha in the Śìmālādevī Sūtra (Sheng-man Ching), "Journal of the American Oriental Society" 1979, vol. 99, no. 2, pp. 191-203.

Paul D., The Sūtra of Queen Śrimālà of the Lion's Roar [in:] D. Paul, J.R. McRae, The Sütra of Queen Śrimālā of the Lion's Roar \& The Vimalakīrti Sūtra, Berkeley 2004.

Radich M., Tathāgatagarbha Sütras [in:] Brill's Encyclopedia of Buddhism, vol. 1: Literature and Languages, J. Silk et al. (eds.), Leiden 2015, pp. 261-273.

Radich M., The Mahāparinirvāna-mahāsūtra and the Emergence of Tathāgatagarbha Doctrine, Hamburg 2015.

Ratnagotravibhāga Mahāyānottaratantraśāstra, J.H. Johnston (ed.), The Bihar Research Society, Patna 1950.

Sasaki S., The Mahāparinirvaṇa Sūtra and the Origins of Mahāyāna Buddhism, "Japanese Journal of Religious Studies" 1999, vol. 26, no. 1-2, pp. 189-197.

Silk J.A., Buddhist Cosmic Unity: An Edition, Translation and Study of the Anūnatvāpūrnatvanird eśaparivarta, Hamburg 2015.

Suzuki T., The Buddhology in the Mahābherīsūtra Inherited from the Saddharmapundarīka, "Journal of Indian and Buddhist Studies" 2002, vol. 50, no. 2, pp. 1017-1013.

Suzuki T., The Recompilation of the Mahāparinirvanasūtra under the Influence of the Mahämeghasūtra, "Journal of Indian and Buddhist Studies" 2001, vol. 49, no. 2, pp. 1007-1003.

Takasaki J., A Study on the Ratnagotravibhāga (Uttaratantra): Being a Treatise on the Tathāgatagarbha Theory of Mahāyāna Buddhism, Rome 1966.

Takasaki J., Nyoraizō shisō no keisei: Indo daijō Bukkyō shisō kenkyū, Tokyo 1975.

Takasaki J., The Tathägatagarbha Theory Reconsidered: Reflections on Some Recent Issues in Japanese Buddhist Studies, "Japanese Journal of Religious Studies" 2000, vol. 27, no. 1-2, pp. 73-83.

Waldron W.S., The Buddhist Unconscious: The Älaya-vijñāna in the Context of Indian Buddhist Thought, London 2003. 
Walshe M., The Long Discourses of the Buddha. A Translation of the Digha Nikāya, Boston 1995. Wayman A., The Mahāsāmghika and the Tathāgatagarbha, "Journal of the International Association of Buddhist Studies" 1978, vol. 1, no. 1, pp. 35-50.

Wayman A., Wayman H., The Lion's Roar of Queen Śrimālā. A Buddhist Scripture on the Tathāgatagarbha Theory, Delhi 1990.

Zimmermann M., A Buddha Within: The Tathāgatagarbhasütra. The Earliest Exposition of the Buddha-Nature Teaching in India, Tokyo 2002.

Zimmermann M., The Process of Awakening in Early Texts on Buddha-Nature in India [in:] A Distant Mirror: Articulating Indic Ideas in Sixth and Seventh Century Chinese Buddhism, L. Chenkuo, M. Radich (eds.), Hamburg 2014, pp. 513-528. 